\title{
CHANGE IN PLATELET COUNT IN PATIENTS WITH HYPERSPLENISM SUBJECTED TO LIVER TRANSPLANTATION
}

\author{
Júlio Cezar Uili COELHO, Priscilla BALBINOT, Rodrigo NITSCHE, Kátia Aparecida PINTO, \\ Mônica Beatriz PAROLIN and Cláudia Alexandra Pontes IVANTES
}

\begin{abstract}
Context - Most patients subjected to liver transplantation presents hypersplenism, which is reversed after the operation. However, some patients remain with moderate to intense hypersplenism. Objective - To study the effect of liver transplantation on platelet count in patients with hypersplenism. Method - Of a total of 233 patients who underwent liver transplantation, 162 were excluded from the present study because of occurrence of steroid-resistant rejection, absence of hypersplenism before the transplantation, absence of follow-up for at least 2 years or incomplete exams data. The electronic study protocols of the remaining 71 patients were reviewed to determine the demographics, etiology of cirrhosis, and results of pathologic examination of the explanted liver. Serial platelet count was obtained from the study protocol on the day before liver transplantation and 1,2,4, and 6 months and 1 year after liver transplantation. Statistical analysis was performed using the Student's $t$-test, chi-square test, and Spearman's correlation test. Results - Posttransplant platelet count at all time intervals was significantly higher than the pretransplant value $(P<0.001$ for all time intervals). Thrombocytopenia was reversed (platelet count $\left.>100,000 / \mathrm{mm}^{3}\right)$ in 58 patients $(81.7 \%) 1$ month after liver transplantation. Twelve patients (16.9\%) remained with thrombocytopenia 1 year after liver transplantation. Three patients $(4.2 \%)$ had recurrence of thrombocytopenia within 1 year after liver transplantation. There was no correlation between pretransplant platelet count and the Child-Pugh class or the MELD score. Conclusion - Liver transplantation reverses hypersplenism in most patients.
\end{abstract}

HEADINGS - Platelet count. Hypersplenism. Liver transplantation.

\section{INTRODUCTION}

Hypersplenism may be defined as the occurrence of leucopenia, thrombocytopenia, and or anemia due to sequestration and destruction of blood elements in enlarged, congested spleen $^{(3,11,16)}$. It is frequently secondary to liver cirrhosis.

The majority of patients subjected to liver transplantation (LT) presents hypersplenism ${ }^{(13,19)}$. Following either cadaveric LT or living-donor LT, spleen volume becomes smaller and hypersplenism is reversed ${ }^{(15,18,19,20)}$. However, about $20 \%$ of these patients remain with moderate to intense hypersplenism 1 year after $\mathbf{L T}^{(6,13)}$. Persistence of hypersplenism following LT may limit use of immunosuppressive agents and other drugs, such as interferon used to treat recurrent hepatitis $\mathrm{C}$ virus infection ${ }^{7,8}$, 9, 14). The effect of LT on hypersplenism has not been evaluated in Brazil yet. The purpose of this study is to evaluate the changes of platelet count in patients with hypersplenism subjected to liver transplantation.

\section{METHODS}

In the period from January 2001 through December 2008, 233 patients with age between 18 and 69 years underwent liver transplantation at the Nossa Senhora das Graças Hospital and Clinical Hospital of the Federal University of Paraná, Curitiba, PR, Brazil. A total of 162 patients was excluded from the present study because of occurrence of steroid-resistant rejection, absence of hypersplenism before LT, presence of posttransplant vascular complications, absence of posttransplant follow-up for at least 2 years or incomplete exams data. According to previous reports, hypersplenism was defined as a leukocyte count of less than 5000/ $\mathrm{mm}^{3}$ and/or a platelet count of less than $100 \times 10^{3} /$ $\mathrm{mm}^{3(5,20)}$. The remaining 71 patients ( 60 deceased-donor liver transplants and 11 living-donor liver transplants) were included in the study.

The electronic study protocols of these 71 patients were reviewed to determine the demographics, etiology of cirrhosis, abdominal ultrasonography, and results of pathologic examination of the explanted liver. Our

Division of Gastrointestinal Surgery and Liver Transplantation of the Hospital Nossa Senhora das Graças and Hospital de Clínicas, Federal University of Paraná, Curitiba, PR, Brazil.

Correspondence: Prof. Júlio Coelho - Rua Bento Viana, 1140 - apt. 2202 - 80240-110 - Curitiba, PR, Brazil. E-mail: coelhojcu@yahoo.com.br 
standard immunosuppressive protocol consisted of tacrolimus or cyclosporine and corticosteroids. Mycophenolate mofetil or mycophenolic acid was also used in 18 patients.

Serial platelet count was obtained from the study protocol on the day before LT and 1,2,4, and 6 months and 1 year after LT. Thrombocytopenia was defined as a platelet count of less than $100 \times 10^{3} / \mathrm{mm}^{3}$. Reversion of thrombocytopenia was defined as a platelet count of more than $100 \times 10^{3} / \mathrm{mm}^{3}$ after the LT. The recurrence of thrombocytopenia was defined as a platelet count of less than $100 \times 10^{3} / \mathrm{mm}^{3}$ in the follow-up period after a previous reversion of thrombocytopenia. Leukocyte counts were not evaluated because of the effect of immunosuppression on the peripheral leukocyte counts ${ }^{(5,19)}$.

The protocol of this study was approved by the Research Committee of the Clinical Hospital of the Federal University of Paraná. Informed consent was waived. Values were expressed as mean $\pm \mathrm{SD}$ (standard deviation). Statistical analysis was performed using the Statistica version 9 software (StatSoft Inc., Tulsa, OK, USA). Student's $t$-test was employed to determine the difference between the means and chi-square test to assess the difference between the expected frequencies and the observed frequencies of the two groups. Spearman's correlation test was used to assess the correlation between platelet count and the Child-Pugh class and the MELD score. Results were considered statistically significant when $P \leq 0.05$.

\section{RESULTS}

The demographics and clinical characteristics of the patients are shown in Table 1. The age of the patients ranged from 18 to 69 years, with an average of $47.0 \pm 11.9$ years (mean \pm SD). Fifty patients $(70.4 \%)$ were male. The main indications for transplantation consisted of hepatitis $\mathrm{C}(\mathrm{n}=$ $23 ; 33.3 \%)$, alcoholic cirrhosis $(\mathrm{n}=12 ; 16.9 \%)$ and hepatitis $\mathrm{B}(\mathrm{n}=10 ; 14.1 \%)$. MELD score was $\leq 20$ in most patients (57 patients; $80.2 \%$ ). For this purpose, additional points were not added to the MELD score of the 24 patients with associated hepatocellular carcinoma.

Table 2 lists the changes in the platelet count according to the posttransplantation time interval. Pretransplant platelet count ranged from 4 to $99\left(\times 10^{3} / \mathrm{mm}^{3}\right)$, with a mean of 64 \pm 27 . Posttransplant platelet count at all time intervals was significantly higher than the pretransplant value $(P<0.001$ for all time intervals). Thrombocytopenia was reversed (platelet count $>100,000 / \mathrm{mm}^{3}$ ) in all but 13 patients $(18.3 \%)$ 1 month after LT. Twelve patients (16.9\%) remained with thrombocytopenia 1 year after LT. Duplex ultrasonography showed no thrombosis of the portal and hepatic veins of
TABLE 1. Demographic and clinical characteristics of the 71 patients included in the study

\begin{tabular}{lc}
\hline Age & Years \\
Mean \pm SD & $47.0 \pm 11.9$ \\
Range & $18-69$ \\
Gender & $\mathbf{n}$ \\
Male & 50 \\
Female & 21 \\
Etiology of liver disease & $\mathbf{n}$ \\
Hepatitis C & 23 \\
Alcoholic cirrhosis & 12 \\
Hepatitis B & 10 \\
Alcoholic cirrhosis + viral hepatitis & 4 \\
Autoimmune cirrhosis & 6 \\
Metabolic diseases & 5 \\
Cryptogenic cirrhosis & 5 \\
Others & 6 \\
Presence of hepatocellular carcinoma & 24 \\
Child-Pugh class & $\mathbf{n}$ \\
A & 13 \\
B & 36 \\
C & 21 \\
MELD score & $\mathrm{n}$ \\
$<10$ & 7 \\
$10-15$ & 31 \\
$16-20$ & 19 \\
$>21$ & 14 \\
\hline
\end{tabular}

all 12 patients. Three other patients $(4.2 \%)$ had temporary recurrence of thrombocytopenia within 1 year after LT.

There was no correlation between pretransplant platelet count and the Child-Pugh class or the MELD score. The pretransplant platelet count was $65 \pm 20,64 \pm 24$, and $63 \pm 34$ for the ChildPugh A, B, and C class, respectively. The pretransplant platelet count was $88 \pm 22,63 \pm 18,53 \pm 31$, and $69 \pm 31$ for the MELD score $<10,10-15,16-20$, and $>21$, respectively.

\section{DISCUSSION}

Advanced liver cirrhosis is by far the most frequent cause of portal hypertension ${ }^{(2,4)}$. Passive congestion of the spleen due to portal hypertension causes splenomegaly and hypersplenism. Sequestration and destruction of blood elements due to hypersplenism cause anemia, thrombocytopenia and or leukopenia. Use of several medications, e.g., interferon, mycophenolate mofetil, and antivirals which are known to reduce blood elements is frequently limited in patients with

TABLE 2. Change in platelet count in patients subjected to liver transplantation according to the postoperative time interval

\begin{tabular}{cccccc}
\hline \multicolumn{5}{c}{ Platelet count $\left(\mathrm{x} 10^{3} / \mathrm{mm}^{3}\right)$} \\
\hline \multirow{2}{*}{ Before LT } & \multicolumn{5}{c}{ After LT } \\
\cline { 2 - 6 } & 1 month & 2 months & 4 months & 6 months & 1 year \\
\hline
\end{tabular}

LT $=$ Liver transplantation

* Platelet count significantly higher than the pretransplant value $(P<0.001)$ 
hypersplenism ${ }^{(16)}$. Hepatitis $\mathrm{C}$ is the most common indication for LT, but unfortunately the virus almost always recurs. Interferon and ribavirin therapy has been widely accepted as the treatment for recurrent disease. However, leucopenia, anemia, and thrombocytopenia which often afflict liver transplant patients, lead to failure to initiate this antiviral regimen, dose reduction, or discontinuation of therapy, which ultimately decreases the likelihood of sustained virological response ${ }^{(16)}$.

Several studies have demonstrated that portosystemic shunt reduces splenic vein pressure and congestion of the spleen, and improves hypersplenism ${ }^{(5,17)}$. It has been presumed that splenomegaly and hypersplenism also resolve following normalization of portal pressure after $\operatorname{LT}^{(4,20)}$. However, the assumption that the spleen would return to normal size and portosystemic collateral would close in all patients after successful LT is incorrect. Portosystemic collaterals and splenomegaly frequently persist for several years after liver transplantation, even in patients with no posttransplantation vascular complications ${ }^{(4)}$. Chezmar et al. ${ }^{(4)}$ have described portosystemic collaterals in $14(74 \%)$ of the 19 patients on CT at 1 year after transplantation. At this time interval, splenic hilar collaterals persisted in $64 \%$ of patients, splenocolic ligament collaterals in $50 \%$, retroperitoneal collaterals in $38 \%$, and peripancreatic collaterals in $38 \%$ of patients. Splenic volume decreased in $94 \%$ of patients examined after transplantation, with a mean reduction of $60 \% \pm 19 \%$. However, the spleen remained significantly enlarged in $56 \%$ of patients.

Chikamori et al. ${ }^{(5)}$ have also reported that the spleen volume reduced significantly from 4 to 40 months after the LT. But, the spleen returned to normal size in only 5 of 47 patients (11\%) after LT. Chezman et al. ${ }^{(4)}$ have also demonstrated that the spleen returned to normal volume in 7 of 17 patients $(39 \%)$ after LT.

Several studies have reported that pretransplant platelet count had a negative correlation with spleen volume, suggesting that thrombocytopenia is due to sequestration and destruction of platelet in enlarged, congested spleen ${ }^{(1,4,5,20)}$. Following LT, platelet count increases and the spleen reduces in size.
Our study demonstrated that LT reverses hypersplenism in the majority of patients, as previously reported by others ${ }^{(10}$, ${ }^{19,20)}$. Our data show that platelet count increases rapidly after LT and reaches a plateau 1 month after LT and then remains stable thereafter. Yanaga et al. ${ }^{(20)}$ and Chikamori et al. ${ }^{(5)}$ have also observed reversal of thrombocytopenia (platelet count $>100,000 / \mathrm{mm}^{3}$ ) in most patients in 2 weeks and 1 month after LT, respectively.

Other important finding in our study is that preoperative platelet count did not correlate with Child-Pugh class or MELD score. This finding was also reported by Chikamori et al. ${ }^{(5)}$. Child-Pugh class or MELD score correlates with the intensity of liver dysfunction, while thrombocytopenia correlates with spleen size ${ }^{(5)}$.

It has been suggested that in cases of splenomegaly, the structural changes in the spleen, including fibrosis and hyperplasia, do not allow the complete return to normal size following normalization of portal hypertension after $\operatorname{LT}^{(2,4)}$. Thus, some degree of splenomegaly and thrombocytopenia persists in a significant number of patients who have been subjected to $\mathrm{LT}^{(12)}$.

The findings of this and other studies have clinical importance. Persistence of hypersplenism after LT in the absence of other clinical findings does not necessarily mean presence of portal hypertension secondary to recurrent liver disease or the presence of vascular complication. A significant percentage of our patients $(16.9 \%)$ remained with thrombocytopenia 1 year after the LT. All these patients had normal liver function and absence of vascular complications. Persistent posttransplant thrombocytopenia was also reported by others ${ }^{(5,20)}$. As mentioned previously, these patients may have limitation in the use of some medications that cause anemia, thrombocytopenia, and or leukopenia.

\section{CONCLUSIONS}

We conclude that LT reverses hypersplenism in most patients. There is no correlation between pretransplant platelet count and Child-Pugh class or MELD score.

Coelho JCU, Balbinot P, Nitsche R, Pinto KA, Parolin MB, Ivantes CAP. Modificação no número de plaquetas de pacientes com hiperesplenismo submetidos a transplante hepático. Arq Gastroenterol. 2011;48(3):175-8.

RESUMO-Contexto - A maioria dos pacientes submetidos a transplante hepático apresenta hiperesplenismo, que é revertido após a operação. Entretanto, alguns pacientes permanecem com hiperesplenismo moderado a intenso. Objetivo - Avaliar o efeito do transplante hepático na contagem de plaquetas de pacientes com hiperesplenismo. Método - De um total de 233 pacientes que foram submetidos a transplante hepático, 162 foram excluídos do presente estudo devido à ocorrência de rejeição resistente a corticóide, ausência de hiperesplenismo antes do transplante, ausência de seguimento pós-transplante por pelos menos 2 anos ou dados de exames incompletos. O protocolo eletrônico de estudo dos demais 71 pacientes foi revisado para determinar os aspectos demográficos, a etiologia da cirrose e o resultado do exame patológico do fígado explantado. Contagem seriada de plaquetas foi obtida do protocolo de estudo no dia antes do transplante e 1,2, 4 e 6 meses e 1 ano após o transplante. Análise estatística foi realizada empregando o teste $t$ de Student, o teste qui ao quadrado e o teste de correlação de Spearman. Resultados - A contagem de plaquetas pós-transplante em todos os intervalos de tempo foi significantemente maior que os valores pré-transplantes $\left(P<0,001\right.$ para rodos os intervalos de tempo). Trombocitopenia foi revertida (contagem de plaquetas $\left.>100.000 / \mathrm{mm}^{3}\right)$ em 58 pacientes $(81,7 \%) 1$ mês após o transplante. Doze pacientes $(16,9 \%)$ permaneceram com trombocitopenia 1 ano após o transplante. Três pacientes $(4,2 \%)$ tiveram recurrência da trombocitopenia dentro de 1 ano após o transplante. Não houve correlação entre a contagem de plaquetas pré-transplante e a classe de Child-Pugh e o escore de MELD. Conclusão - O transplante hepático reverte o hiperesplenismo na maioria dos pacientes.

DESCRITORES - Contagem de plaquetas. Hiperesplenismo. Transplante hepático. 


\section{REFERENCES}

1. Aseni P, Rimoldi PA, Pirotta V, Pirolo A. Reversal of hypersplenism after liver transplantation. Gastroenterology. 1991;100:1126-8.

2. Bolognesi M, Sacerdoti D, Bombonato G, Merkel C, Sartori G, Merenda R, Nava V, Angeli P, Feltracco P, Gatta A. Change in portal flow after liver transplantation: effect on hepatic arterial resistance indices and role of spleen size. Hepatology. 2002;35:601-8.

3. Chang JH, Choi JY, Woo HY, Kwon JH, You CR, Bae SH, Yoon SK, Choi MG, Chung IS, Kim DG. Severe thrombocytopenia before liver transplantation is associated with delayed recovery of thrombocytopenia regardless of donor type. World J Gastroenterol. 2008;14:5723-9.

4. Chezmar JL, Redvanly RD, Nelson RC, Henderson JM. Persistence of portosystemic collaterals and splenomegaly on CT after orthotopic liver transplantation. AJR Am J Roentgenol. 1992;159:317-20.

5. Chikamori F, Nishida S, Selvaggi G, Tryphonopoulos P, Moon JI, Levi DM, Kato T, Island ER, Maki A, Tekin A, Tzakis AG. Effect of liver transplantation on spleen size, collateral veins, and platelet counts. World J Surg. 2010;34: 320-6.

6. Egami S, Sugawara Y, Mizuta K, Kaneko J, Kawarasaki H, Makuuchi M. Effect of pediatric living-donor liver transplantation on splenomegaly. Transplantation. 2002; $74: 1639-42$

7. Forman LM, Lewis JD, Berlin JA, Feldman HI, Lucey MR. The association between hepatitis $\mathrm{C}$ infection and survival after orthotopic liver transplantation. Gastroenterology. 2002;122:889-96.

8. Gane E. The natural history and outcome of liver transplantation in hepatitis $\mathrm{C}$ virus-infected recipients. Liver Transpl. 2003;9:s28-s34.

9. Gordon FD, Kwo P, Vargas HE. Treatment of hepatitis $\mathrm{C}$ in liver transplant recipients. Liver Transpl. 2009;15:126-35.

10. Ishifuro M, Horiguchi J, Ohshita A, Itamoto T, Ohdan H, Ito K. Remission of splenic volume in the recipient during the course of adult-to-adult living donor liver transplantation: evaluation using multislice computed tomography and semiautomatic software. Transplant Proc. 2009;41:3772-4.
11. Kaneko J, Sugawara Y, Akamatsu N, Kokudo N, Makuuchi M. Spleen volume and platelet number changes after living donor liver transplantation in adults. Hepatogastroenterology. 2004;51:262-3.

12. Piscaglia F, Zironi G, Gaiani S, Mazziotti A, Cavallari A, Gramantieri L, Valgimigli M, Bolondi L. Systemic and splanchnic hemodynamic changes after liver transplantation for cirrhosis: a long-term prospective study. Hepatology. 1999;30:58-64.

13. Pozzato C, Marzano L, Larghi A, Uslenghi E, Quagliuolo M. Splenomegaly and hypersplenism in cirrhotic patients before and after orthotopic liver transplantation. Eur J Ultrasound. 1997;6:43-7.

14. Prieto M, Berenguer M, Rayón JM, Córdoba J, Argüello L, Carrasco D, García-Herola A, Olaso V, De Juan M, Gobernado M, Mir J, Berenguer J. High incidence of allograft cirrhosis in hepatitis $\mathrm{C}$ virus genotype $1 \mathrm{~b}$ infection following transplantation: relationship with rejection episodes. Hepatology. 1999;29:250-6.

15. Shah SH, Hayes PC, Allan PL, Nicoll J, Finlayson ND. Measurement of spleen size and its relation to hypersplenism and portal hemodynamics in portal hypertension due to hepatic cirrhosis. Am J Gastroenterol. 1996;91:2580-3.

16. Sibulesky L, Nguyen JH, Paz-Fumagalli R, Taner CB, Dickson RC. Treatment modalities for hypersplenism in liver transplant recipients with recurrent hepatitis C. World J Gastroenterol. 2009;15:5010-3.

17. Soper NJ, Rikkers LF. Effect of operations for variceal hemorrhage on hypersplenism. Am J Surg. 1982;144:700-3.

18. Tutar NU, Isiklar I, Ulu EM, Haberal M. Spleen size changes in pediatric liver transplant recipients with functioning grafts. Transplant Proc. 2007;39: 3199-201.

19. Witte M, Langnas AN, Hirst K, Stratta RJ, Shaw BW Jr. Impact of liver transplantation on the reversal of hypersplenism. Transplant Proc. 1993;25:1987.

20. Yanaga K, Tzakis AG, Shimada M, Campbell WE, Marsh JW, Stieber AC, Makowka L, Todo S, Gordon RD, Iwatsuki S, Starzl TE. Reversal of hypersplenism following orthotopic liver transplantation. Ann Surg. 1989;210:180-3.

Received 25/10/2010 Approved 12/1/2011. 